\title{
Diversity and Ecology of Periphytonic Algae in the Arys River Basin, Kazakhstan
}

\author{
Barinova SS ${ }^{*}$, Krupa $\mathrm{EG}^{2}$ \\ ${ }^{1}$ Institute of Evolution, University of Haifa, Israel \\ ${ }^{2}$ Republican State Enterprise on the Right of Economic Use "Institute of Zoology", \\ Ministry of Education and Science, Science Committee, Republic of Kazakhstan
}

*Corresponding author: Barinova SS, Institute of Evolution, University of Haifa,

\section{Research Article}

Volume 1 Issue 1

Received Date: June 27, 2017

Published Date: July 15, 2017

DOI: $10.23880 /$ jenr-16000106

Mount Carmel, 199 Abba Khoushi Ave., Haifa 3498838, Israel, E-mail: sophia@evo.haifa.ac.il

\section{Abstract}

No one information about algal community diversity from the Arys River basin was before this study. The first data about algal and cyanobacteria species diversity was represented for the Arys River basin and compared it to freshwater algae patterns of the related mountain regions. Altogether 82 species were found in 28 samples of phytoperiphyton on 13 sampling stations of the Arys River and its tributaries. Diatoms prevail in studied algal flora. Bioindication characterize the Arys River waters as temperate, moderately oxygenated, fresh, neutral water affected by a low to moderate level of organic pollution, Class II-III of water quality. The pattern of algae and cyanobacteria diversity distribution depends on altitude and local climatic and environmental conditions. Bacillariophyta species was richest in high mountain habitats, green algae, cyanobacteria and charophytes avoid high mountain habitats and have negative correlation with altitude. These results can be used as indicator of environmental changes in the mountainous areas. Three floristic groups were recognized in the studied river communities corresponding to the upper, middle and lower parts of the watershed. The general trend is an increase of species diversity from lowland areas to the high mountains. Our analysis revealed the altitude of habitat and related climatic factors control over the major diversity patterns in the Arys River basin, the second largest river in Southern Kazakhstan.

Keywords: Algae; Phytoperiphyton; River; Bioindication; Water quality

\section{Introduction}

It is very important to know about algal diversity in fresh waters because most of algal species can be used as environmental indicators. Whereas algal diversity in the lakes of Kazakhstan is partly studied [1-3], the research in the riverine aquatic objects of Kazakhstan region still remains at an initial stage. The aim of this work was enriching of algal and cyanobacteria diversity in the Kazakhstan in particular in the largest Syrdarya River 


\section{Journal of Ecology \& Natural Resources}

basin, the Arys River, and revealing of major environmental factors, which regulated of algal species distribution. The main characteristic of the southern Kazakhstan region is the high range of altitude and sharp seasonality of climate. The elevation plays a larger role in regulating plant species richness patterns. The altitudinal studies of high plant diversity distribution are very developed especially for the rare species. Nevertheless, from the standpoint of the factors, which regulate distribution the study of common species, are the most important [4]. The diversity-temperature relationship for the high plants is well-known [5]. Whereas study of altitude-diversity correlation for diverse groups of plants, bryophytes, and lichens is developed, it is not clear for freshwater algal communities [6,7]. The studied area have altitude gradient from high mountains to the flood plain as well as it is under anthropogenic impact and transformation. Because some study of algal communities from the rivers that have a significant altitude gradient revealed correlation of community structure with habitat altitude [3,7-11], we hypothesize that comparison of species diversity of the Arys River and its tributaries will help in revealing trends of algal diversity under climatic impacts for the central Asian unstudied river also. Methods used to reveal environmental impacts with the help of ecological indicators are the community structure fluctuation analysis, bioindication of major impacting factors, and statistical approaches, linking the community structural and functional aspects with environmental fluctuation [12].

\section{Description of the Study Area}

The Arys River is the largest right tributary of the Syrdarya River in Kazakhstan (Figures 1 \& 2). The river flows in an E-W direction at an altitude ranging from 1,500 to $200 \mathrm{~m}$ a.s.l. [13]. It starts from springs on the north-western slopes of Talas Alatau at an altitude of about $1,513 \mathrm{~m}$. The left tributaries of the Arys are the Aksu, Sairamsu, Jetimsay, Jabaglysu, also originate on the slopes of Talas Alatau, and the Badam River on the mountains of Karzhantau (Figure 3). The sources of the right tributaries are located in the spur of the Karatau Mountains - the Boralday ridge. The area of the Arys River basin together with its tributaries is 14.9 thousand $\mathrm{km}^{2}$. The territory of the Arys River basin, one of the most densely populated in Kazakhstan, is used to grow cereals, cotton, rice, vegetables, grapes, pasture sheep. The region is rich in deposits of minerals [14]. The climate is continental. Winter is moderately warm, with thaws of up to $+10^{\circ} \mathrm{C}$ and cold snap to $-15^{\circ} \mathrm{C}$. Summers are hot, long, with a maximum air temperature of up to $+49^{\circ} \mathrm{C}$. The average annual precipitation is $100-200 \mathrm{~mm}$, in mountainous areas in places up to $1,600 \mathrm{~mm}$ [13].

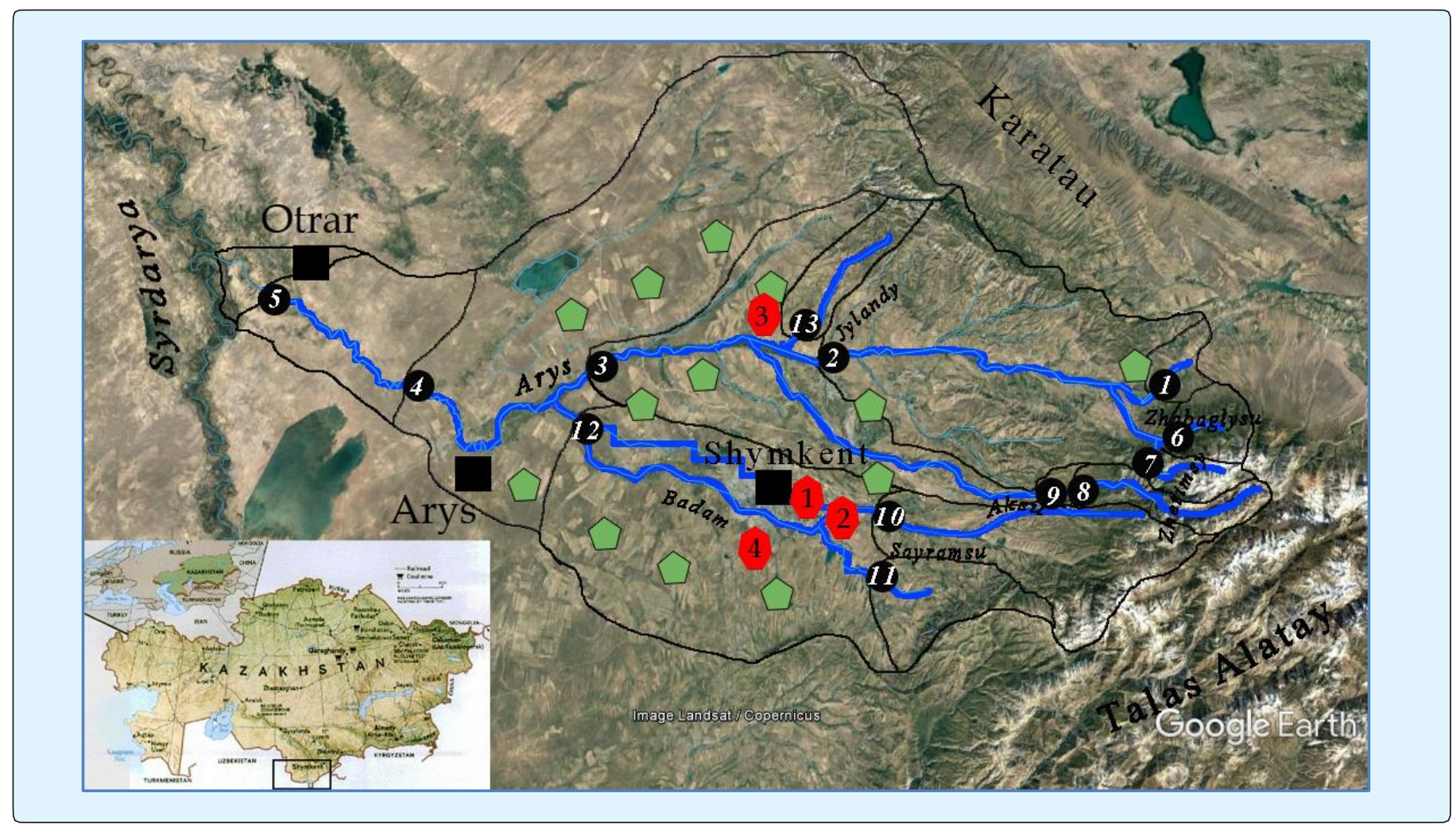

Barinova SS and Krupa EG. Diversity and Ecology of Periphytonic Algae in the Arys River Basin, Kazakhstan. J Ecol \& Nat Resources 2017, 1(1): 


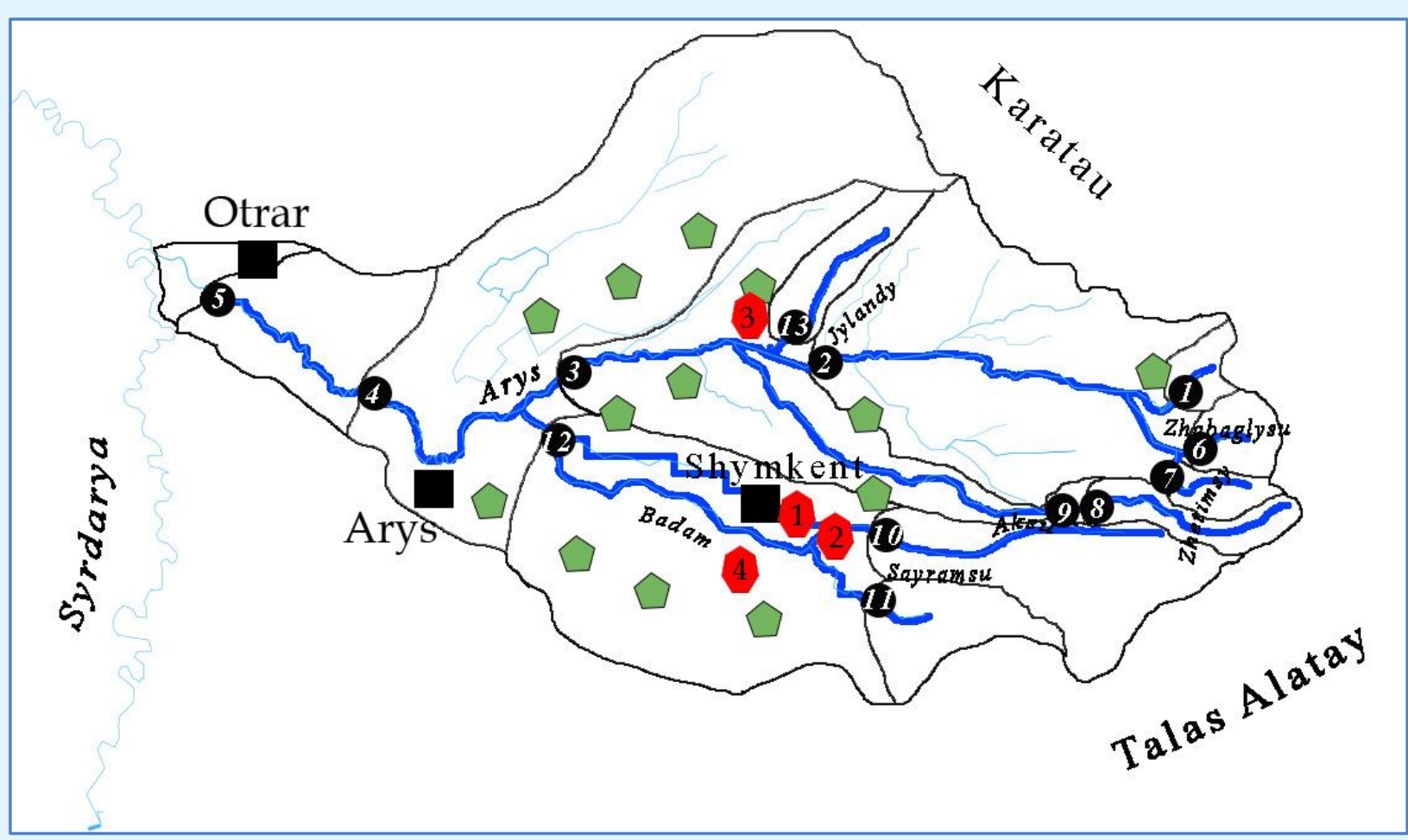

Figure 1: The Arys River basin in Southern Kazakhstan with sampling stations in June 2016, and pollution points. Black squares are cities; Black circles with white numbers are sampling stations; Green polygons are agricultural fields. Red polygons are sources of industrial pollution: 1 - Industrial enterprises of Shymkent, 2, 3 - Cement plants, 4 - Industrial waste dump.

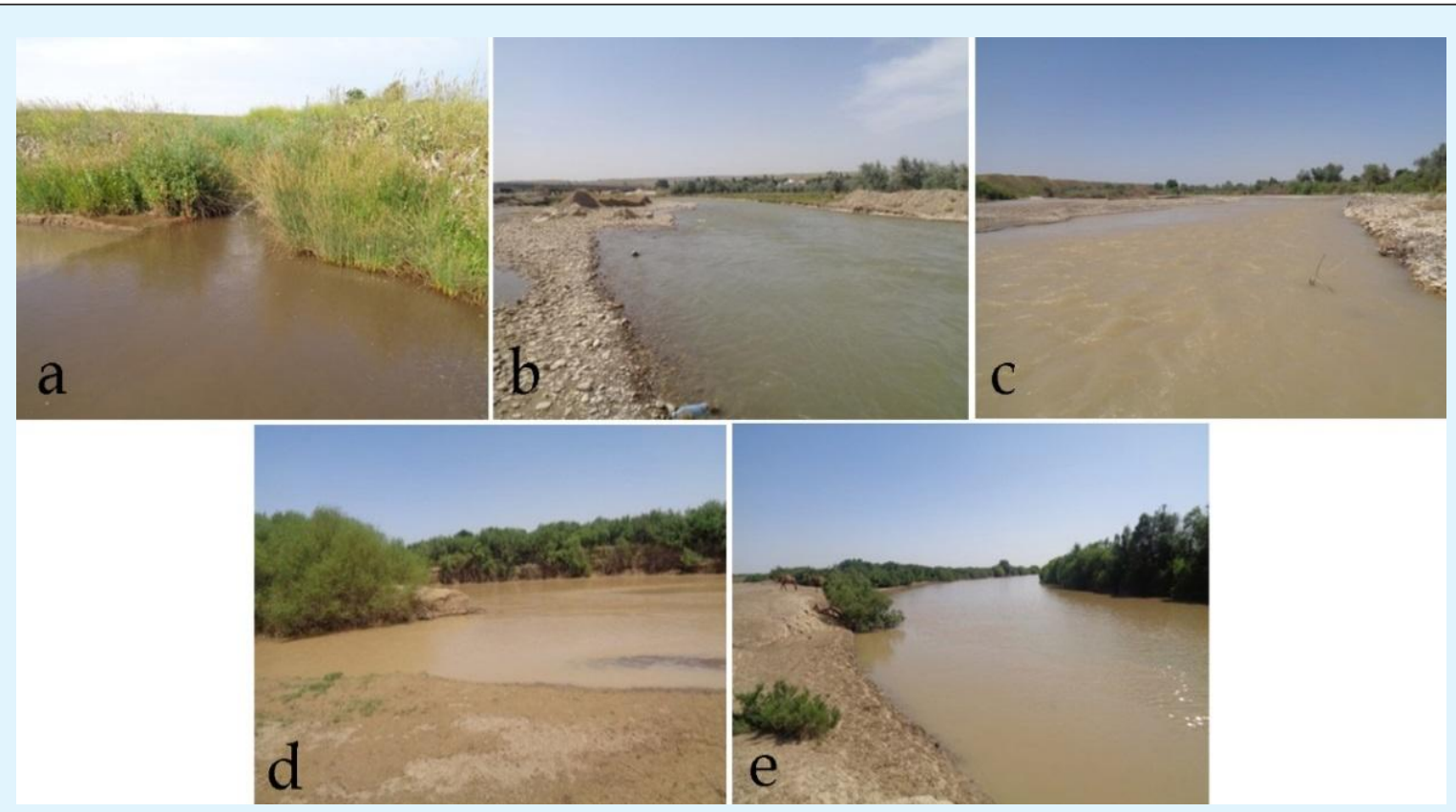

Figure 2: The Arys River sampling stations in June 2016: a: station 1, b: station 2, c: station 3, d: station 4, e: station 5. 


\section{Journal of Ecology \& Natural Resources}

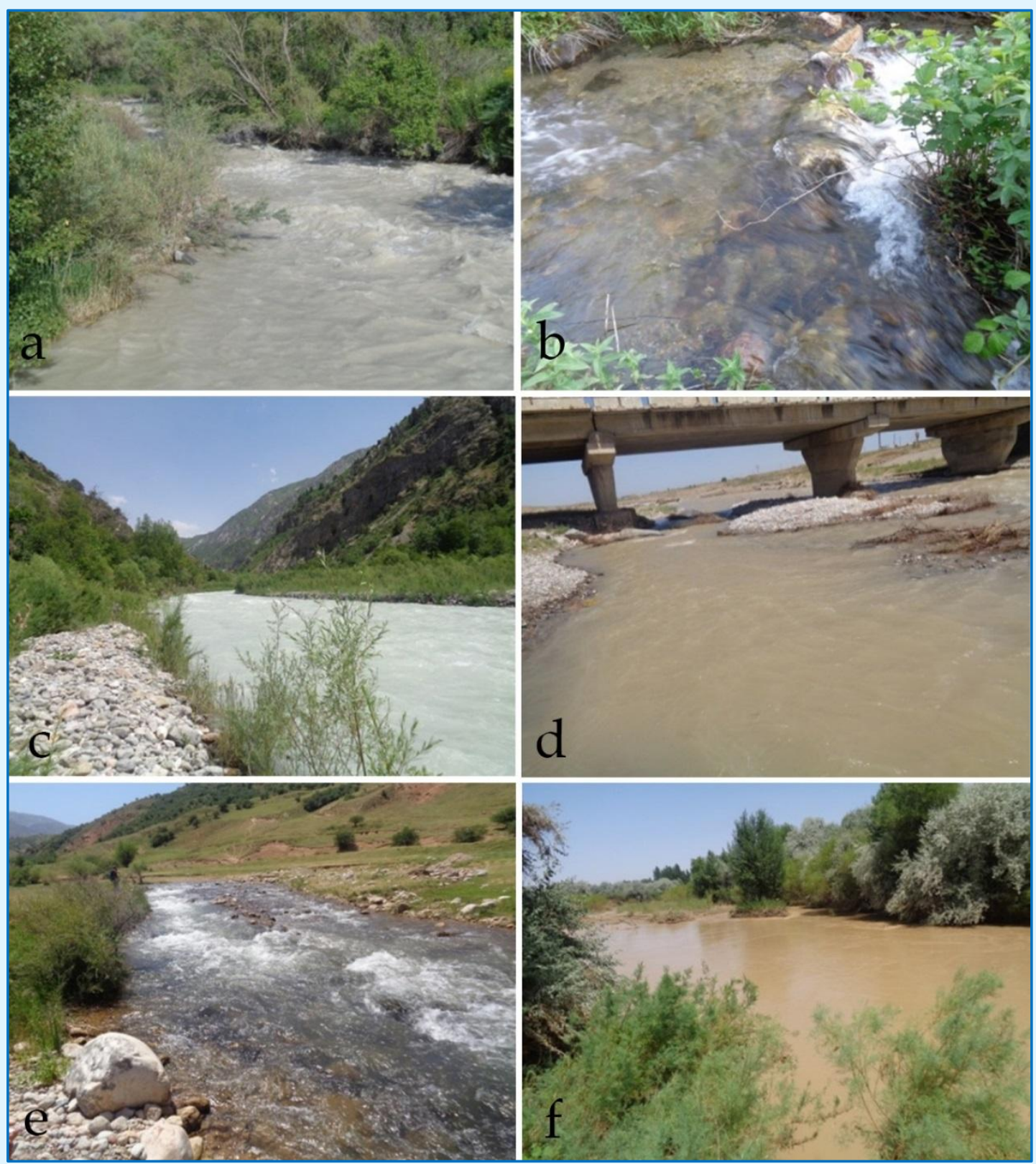

Figure 3: The Arys River tributaries in June 2016: a: Jabaglysu; b: Jetimsay; c: Aksu; d: Sayramsu; e: Badam; middle reaches; f: Badam, lower reaches.

\section{Material and Methods}

Studies of 28 samples of phytoperiphyton were carried out in June 2016 on the 13 stations. The algal samples were obtained by scratching of periphyton and fixed in $4 \%$ formaldehyde [15].
Samples of water were taken at the same stations to determine the total content of dissolved salts, the content of nutrients and heavy metals. All collected samples were transported to the lab in an icebox. Conventional methods of chemical analysis of water were used [16,17]. Water samples were analyzed in three - four replications. The error of estimate for major ions in the water was 0.5$5.0 \%$, depending on the analyte. The measures of the 


\section{Journal of Ecology \& Natural Resources}

temperature and $\mathrm{pH}$ values of the surface water layers was measured with Secchi disk. Coordinate referencing of the stations was done by Garmin eTrex GPS-navigator.

For the processing of phytoperiphyton samples, the settling method was used [18]. Species identification of periphytonic algae was performed by using handbooks for relevant divisions [19-23]. The statistical methods such as the GRAPHS program [24] used for the comparative floristics and Statistica 12.0 for surface plots of the least square method. New method of spatial mapping construction was used for analysis of taxonomical and environmental variables' relationship [25].

The ecological characteristics of algal species were obtained from the database compiled for freshwater algae of the world from multiple analyses of algal biodiversity by Barinova SS, et al. [26], with additions of H. van Dam [27], according to substrate preference, temperature, oxygenation, $\mathrm{pH}$, salinity, organic enrichments, $\mathrm{N}$-uptake metabolism, and trophic states. The ecological groups were separately assessed according to their significance for bioindications. Species that respond were taken in the field environment. Water transparency predictably to environmental conditions were used as bioindicators for particular variables of aquatic ecosystems, the dynamics of which are related to environmental changes. The statistical methods are those recommended by V. Heywood for the development of floristic and taxonomic studies [12].

\section{Results and Discussion}

\section{Environmental Variables}

The streams of the Arys River basin are located at different altitude, with which the distinct zonal-climatic variability of a number of parameters is associated. During the study period, the water temperature ranged from 10.2 to $27.0^{\circ} \mathrm{C}$, rising in the direction from the upper to the lower sections of the rivers. At $\mathrm{pH}$ values of 7.5-8.9, the rivers in the upper stream had more alkaline water relative to the flat areas. The water dissolved salts varied from 160.1 to $526.0 \mathrm{mg} \mathrm{dm}^{-3}$, with the minimum value of the variable in the mountainous areas of the left tributaries. The highest water salinity was in the Arys River lower reaches as well as in the Zhylandy tributary whereas water of whole river was soft and fresh. Table 1 show water depth was varied between 0.1-2.0 m, and water transparency was very low.

\begin{tabular}{|c|c|c|c|c|c|c|}
\hline Name & No Station & Depth, m & Transparency, m & Altitude, m a.s.l. & North & East \\
\hline Arys & 1 & $0.10-0.15$ & 0.05 & 1135 & $42^{\circ} 30^{\prime} 37.0$ & $70^{\circ} 37^{\prime} 14.6$ \\
\hline Arys & 2 & $0.7-0.8$ & 0.2 & 494 & $42^{\circ} 34^{\prime} 50.91$ & $69^{\circ} 58^{\prime} 20.57$ \\
\hline Arys & 3 & & 0.1 & 289 & $42^{\circ} 35^{\prime} 13.8$ & $69^{\circ} 18^{\prime} 31.6$ \\
\hline Arys & 4 & $1.0-1.5$ & 0.1 & 231 & $42^{\circ} 27^{\prime} 52.2$ & $69^{\circ} 57^{\prime} 02.5$ \\
\hline Arys & 5 & $1.5-2.0$ & 0.2 & 205 & $42^{\circ} 41^{\prime} 16.26$ & $68^{\circ} 27^{\prime} 13.18$ \\
\hline Jabaglysu & 6 & $1.3-1.4$ & 0.1 & 1330 & $42^{\circ} 25^{\prime} 11.3$ & $70^{\circ} 33^{\prime} 00.7$ \\
\hline Jetimsay & 7 & $0.3-0.4$ & $0.3-0.4$ & 1513 & $42^{\circ} 24^{\prime} 18.7$ & $70^{\circ} 32^{\prime} 50.1$ \\
\hline Aksu & 8 & $1.5-1.8$ & 0.2 & 1469 & $42^{\circ} 20^{\prime} 06.3$ & $70^{\circ} 27^{\prime} 10.1$ \\
\hline Well & 9 & $0.10-0.15$ & $0.10-0.15$ & 873 & $42^{\circ} 20^{\prime} 06.3$ & $70^{\circ} 27^{\prime} 10.1$ \\
\hline Sayramsu & 10 & 1.5 & 0.2 & 960 & $42^{\circ} 15^{\prime} 50.14$ & $69^{\circ} 57^{\prime} 22.96$ \\
\hline Badam & 11 & $0.7-0.8$ & $0.7-0.8$ & 251 & $42^{\circ} 06^{\prime} 02.7$ & $69^{\circ} 57^{\prime} 48.2$ \\
\hline Badam & 12 & $1.5-2.0$ & 0.1 & $42^{\circ} 30^{\prime} 08.6$ & $69^{\circ} 04^{\prime} 14.2$ \\
\hline Jilandy & 13 & $0.2-0.3$ & $0.2-0.3$ & 723 & $42^{\circ} 35^{\prime} 56.2$ & $70^{\circ} 14^{\prime} 25.3$ \\
\hline
\end{tabular}

Table 1: Sampling stations on the Arys River basin with coordinates and major environmental variables, June 2016.

\section{Taxonomic Structure}

Altogether 82 taxa of algae and cyanobacteria were revealed from 28 samples of phytoperiphyton that were collected from 13 stations of the Arys River and its tributaries in June of 2016. The taxonomic structure of algal communities of the Arys River basin is represented in Table 2 with species ecological preferences and distribution over the altitude layers of its habitats. Of four taxonomic divisions represented in the flora, the
Bacillariophyta is the most species rich with 51 taxa (Table 2, Figure 4) in which Nitzschia with 9 taxa and Cymbella with 6 taxa were the most richest genera. The three other Divisions has significantly lower species number such as Cyanobacteria (20 taxa), Chlorophyta (7 taxa), and Charophyta (4 taxa). Altitudinal distribution of revealed species was not so clear in the species list and therefore need to implement of statistical methods. Green and charophyte algae that are mostly plankton 
inhabitants enriched the periphytonic community from the lower altitude layer about $200 \mathrm{~m}$ a.s.l. It can be because in the river plane represented low streaming channel parts. The middle altitude habitats up to $1,000 \mathrm{~m}$ a.s.l. have altogether 36 species that were not only typical submerged substrate inhabitants such as Cymbella, Diatoma, and Encyonema from diatoms but also planktonic or plankto-benthic cyanobacteria from Phormidium, Planktolyngbya, and Pseudanabaena, with low streaming water diatoms of Fragilaria, Tryblionella, and Ulnaria. It can be related with the flat part of the Arys River middle reaches and its left tributaries Badam and Sayramsu where the stream speed is low (Figures 2b,c, $3 \mathrm{~d}, \mathrm{f})$. In the high altitude part of the river basin, we can see that mostly diatoms of the genera Diatoma, Encyonema, Cymbella, Nitzschia, and Surirella enriched communities on the altitude of about $1,500 \mathrm{~m}$.

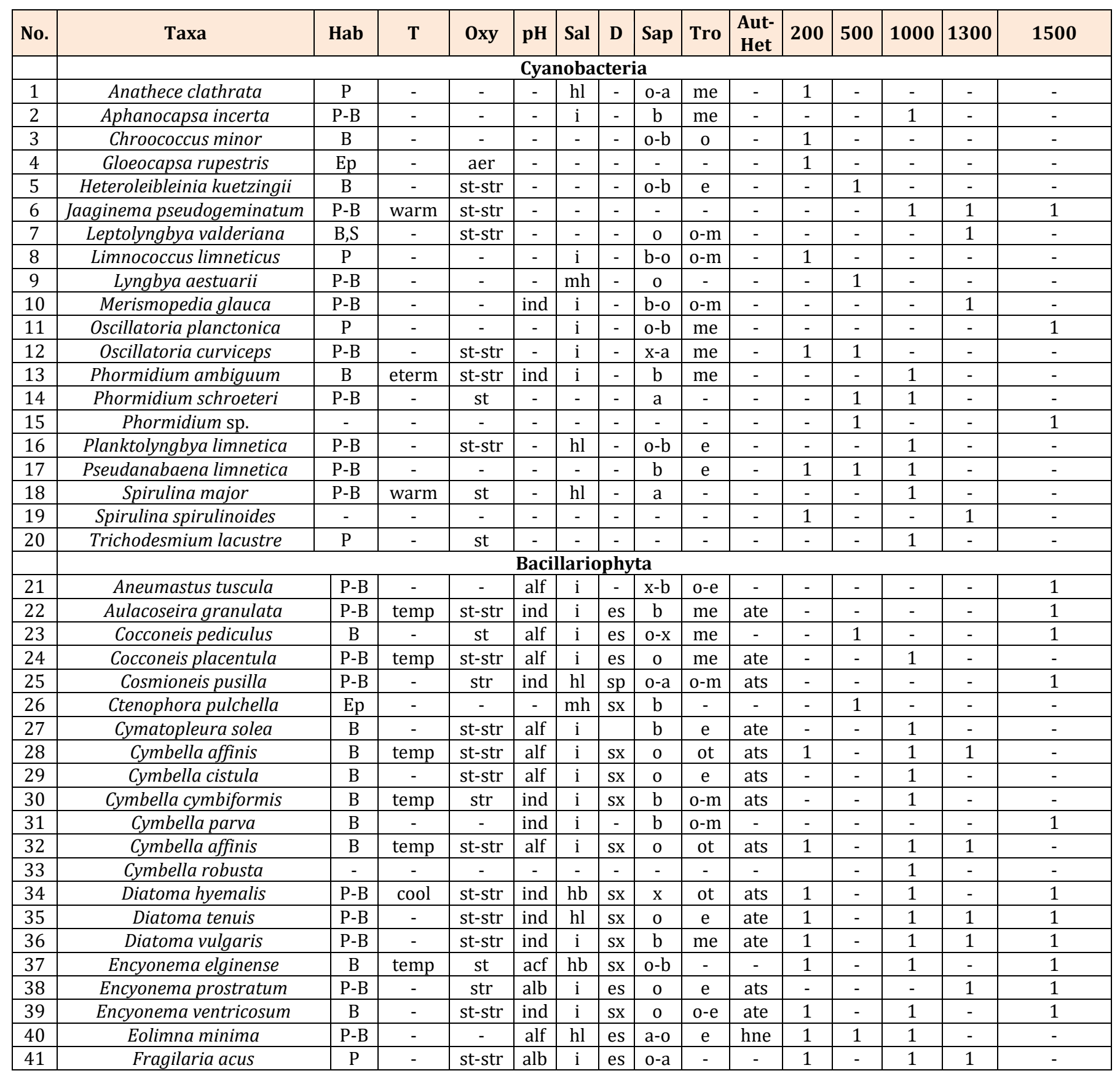




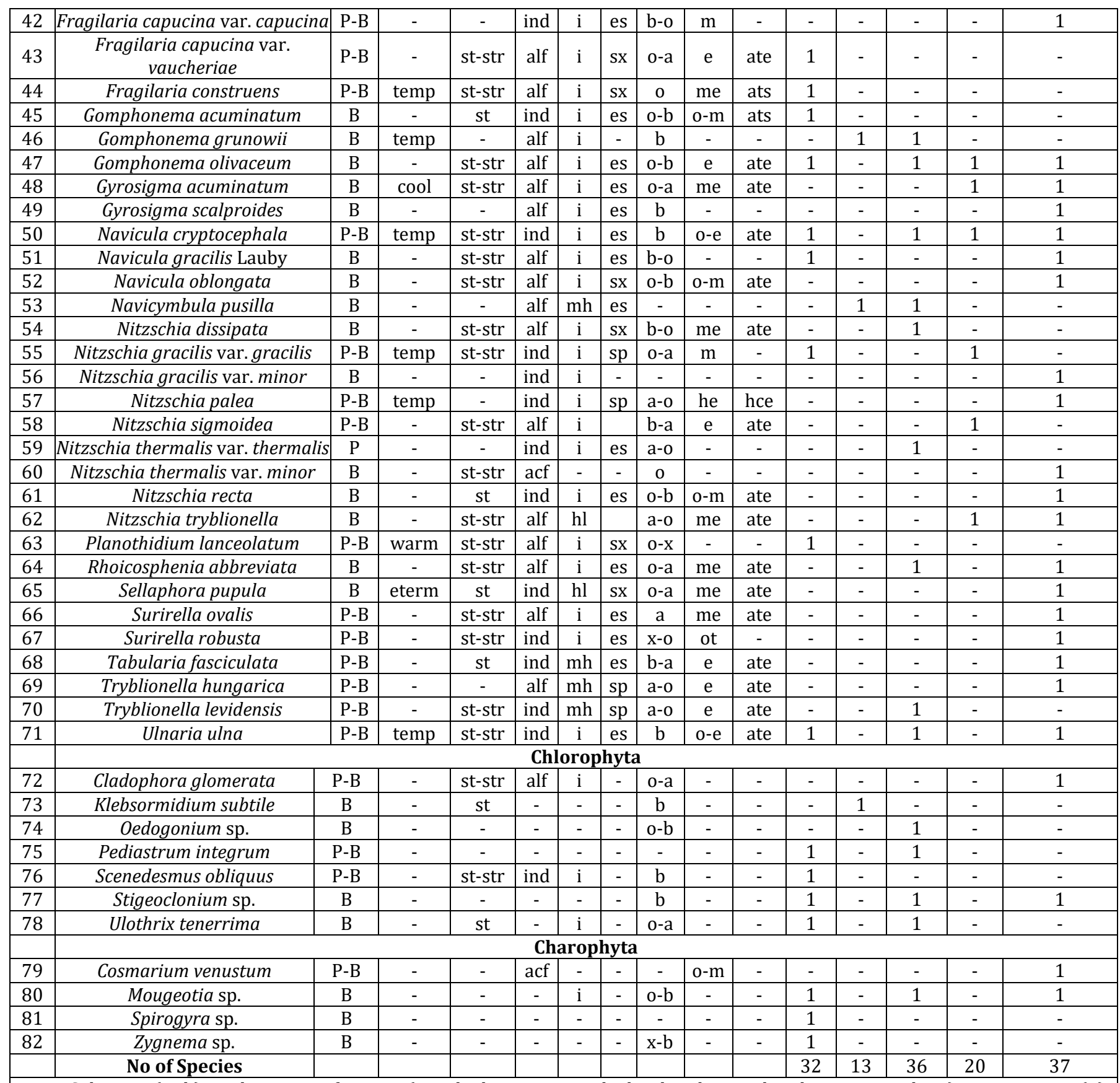

Note. Substrate (Hab) - substrate preferences (P - planktonic, P-B - plankto-benthic, B - benthic, Ep - epiphyte); Temperature (T) - temperature preferences (cool - cool-water, temp - temperate, eterm - eurythermic, warm - warm-water); Oxygenation (Oxy) streaming and oxygenation (st - standing water, str - streaming water, st-str - low streaming water, aer - aerophiles); Salinity (Hal) - halobity degree (hb - oligohalobes-halophobes, i - oligohalobes-indifferent, mh - mesohalobes, hl - halophiles); Acidity $(\mathrm{pH})$ - pH degree on the (alb-alkalibiontes; alf - alkaliphiles, ind - indifferents; acf - acidophiles); Saprobity DAIpo (D) - degree of saprobity according the Watanabe (sx - saproxenes, es - eurysaprobes, sp - saprophiles); Autotrophy-Heterotrophy (Het) nitrogen uptake metabolism [27] (ats - nitrogen-autotrophic taxa, tolerating very small concentrations of organically bound nitrogen; ate - nitrogen-autotrophic taxa, tolerating elevated concentrations of organically bound nitrogen; hne - facultatively nitrogen-heterotrophic taxa, needing periodically elevated concentrations of organically bound nitrogen; hce - obligately nitrogenheterotrophic taxa, needing continuously elevated concentrations of organically bound nitrogen); Trophy (Tro) - trophic state [27] (ot - oligotraphentic; om - oligo-mesotraphentic; m - mesotraphentic; me - meso-eutraphentic; e - eutraphentic; he - 
hypereutraphentic; o-e - oligo- to eutraphentic (hypereutraphentic)); Saprobity S (Sap) - degree of saprobity according to Sládeček (x - xenosaprobes, x-o - xeno-oligosaprobes, o-x - oligo-xenosaprobes, $\mathrm{x}-\mathrm{b}$ - xeno-betamesosaprobes, o - oligosaprobes, o-b oligo-betamesosaprobes, x-a - xeno-alphamesosaprobes, b-o - beta-oligosaprobes, b - betamesosaprobes, b-a - betaalphamesosaprobes, o-a - oligo-alphasaprobes, a-o - alpha- oligosaprobes, a - alphamesosaprobes)

Table 2: Diversity and ecology of algal and cyanobacteria species of the Arys River and its tributaries in summer 2016 and species distribution over the altitude belts.

\section{Bioindication of the Arys River Basin Environment}

The bioindication analysis gives us the basis for assessing sustainability of ecosystems represented in the Arys River, and therefore for evaluating the effectiveness of environmental protection management in Kazakhstan. The bioindication results are presented in Figures 4-6. It is evident that each group of analysis includes a wide ecological range of indicator species, but the trend lines for each variable cuts off the middle indicator group, except for indicators of trophic state (Figure 6). As a result of this analysis it is possible to conclude, that aquatic communities of the Arys River basin formed benthic and periphytonic communities which indicated temperate, moderate oxygenated, fresh, low alkaline neutral water at the low or moderate level of organic pollution, Class II-III of water quality. Therefore, bioindication shows that the Arys River has only slightly anthropogenically influenced algal communities.

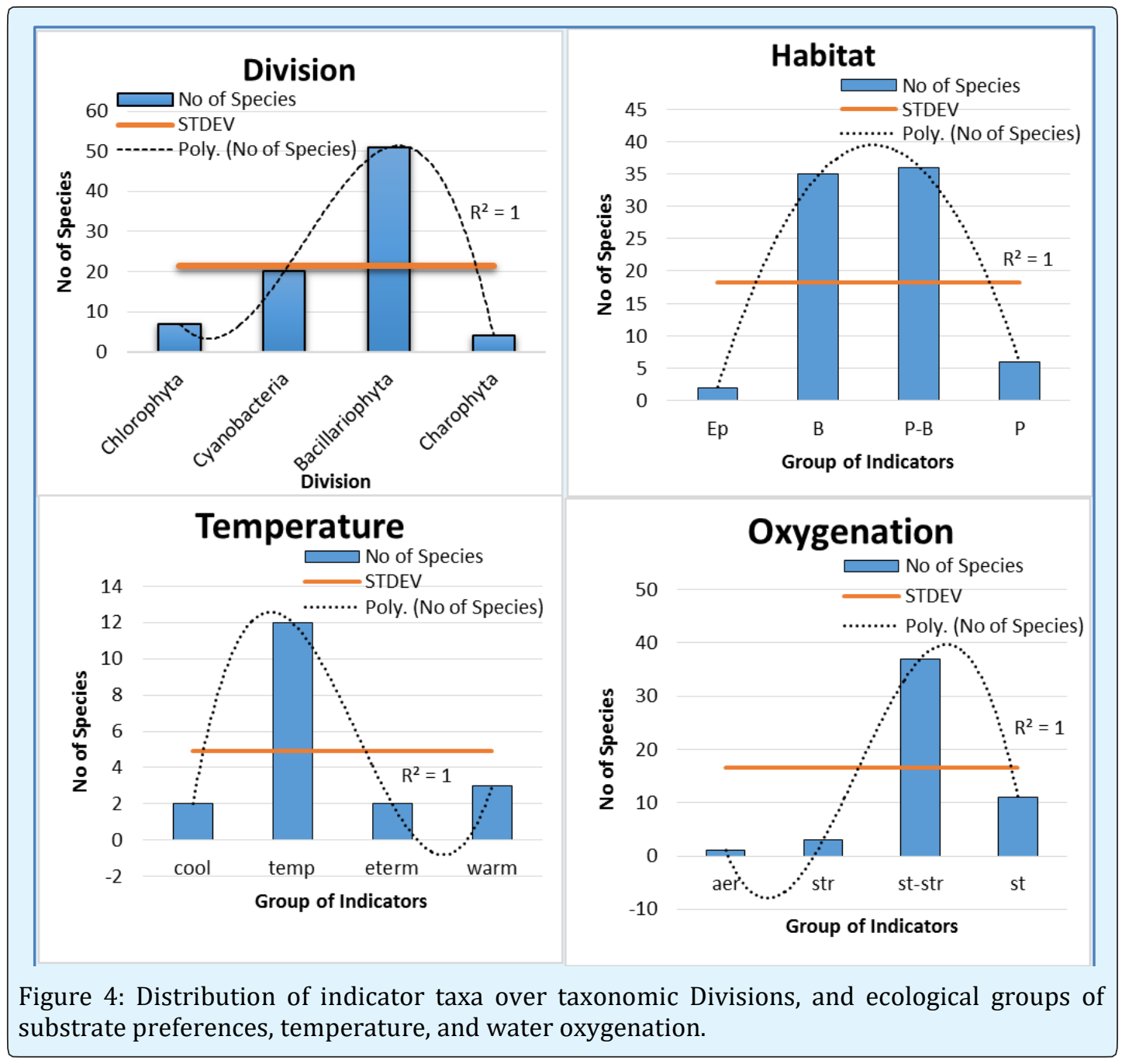

Barinova SS and Krupa EG. Diversity and Ecology of Periphytonic Algae in the Arys River Basin, Kazakhstan. J Ecol \& Nat Resources 2017, 1(1): 


\section{Journal of Ecology \& Natural Resources}

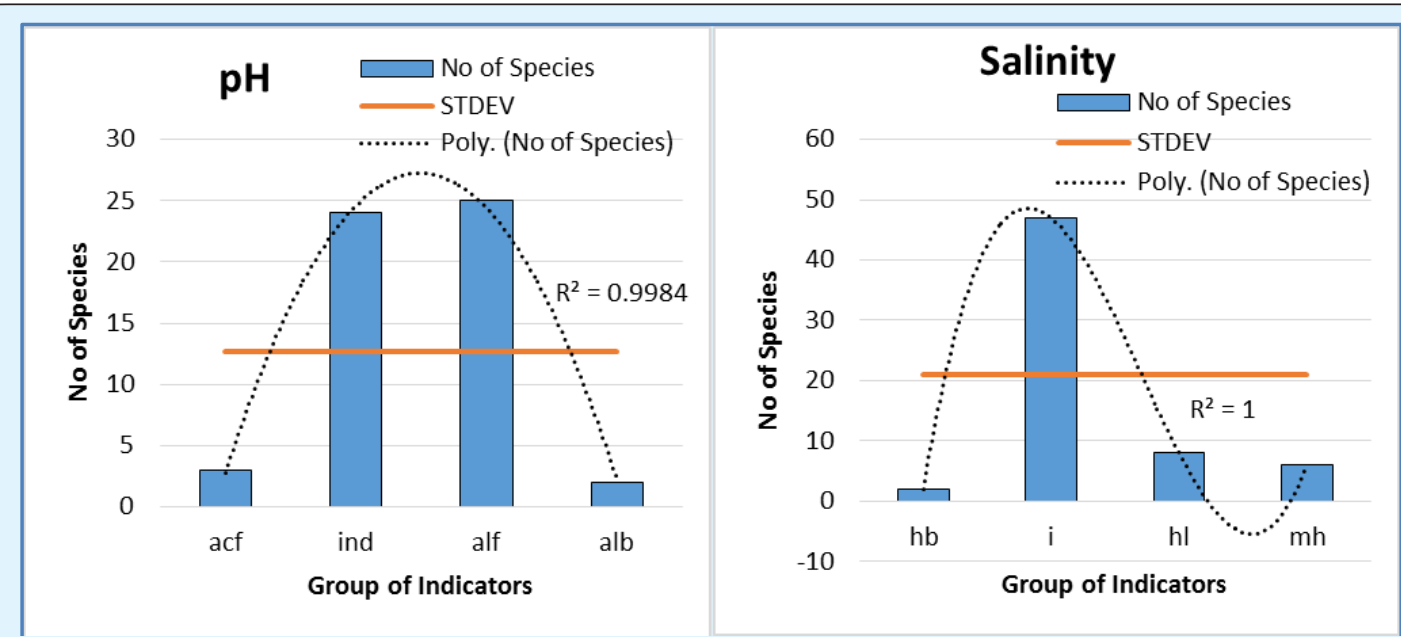

Figure 5: Distribution of indicator taxa ecological groups of water $\mathrm{pH}$ and salinity.

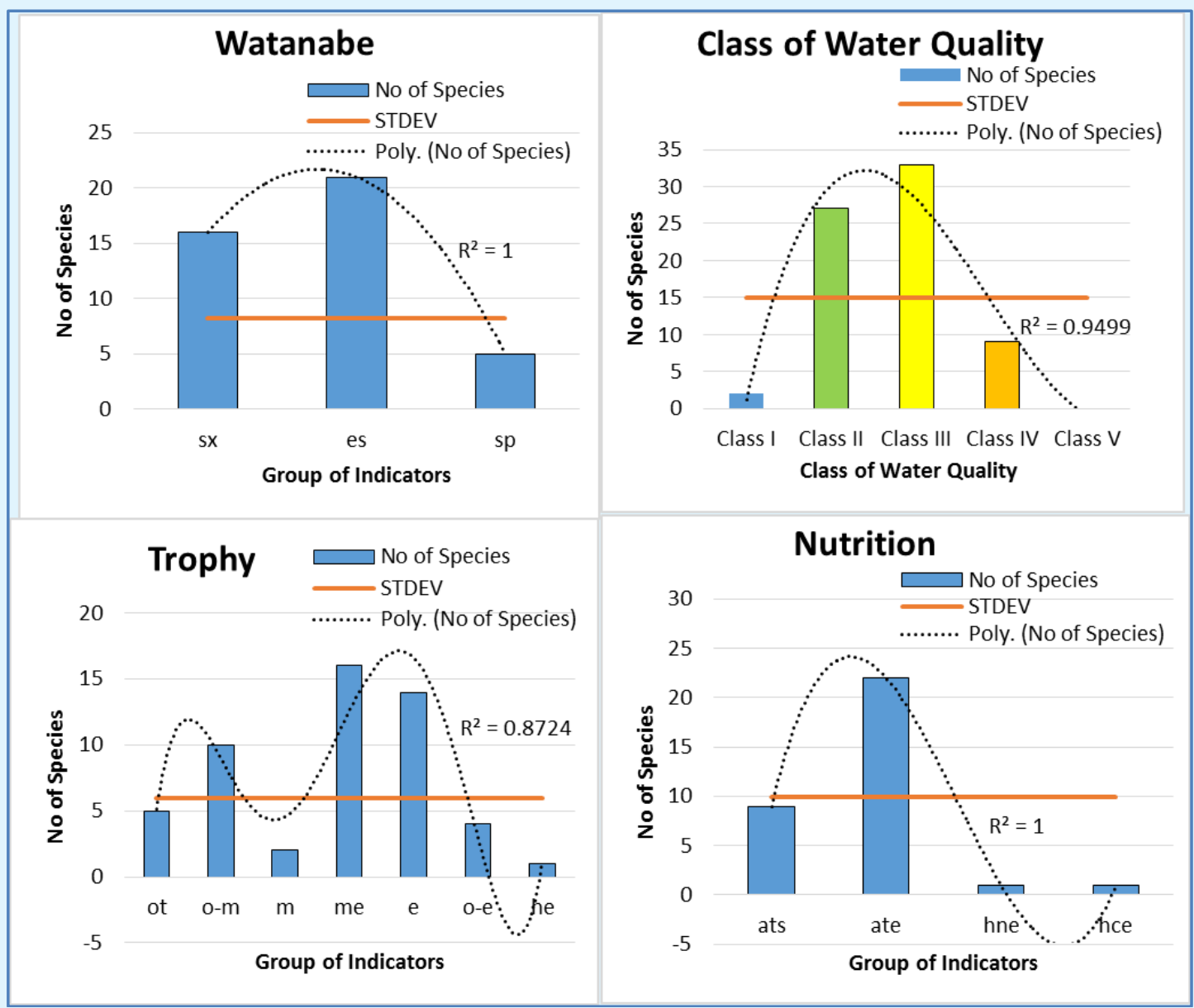

Figure 6: Distribution of indicator taxa over ecological groups of organic pollution according Watanabe, Class of Water Quality according Sládeček, trophic state, and nutrition type. The colors for Class of Water Quality are as in the EU color code. 


\section{Comparative Floristics of the Arys River communities}

Comparative floristic approach provide for the grouping of algal communities in respect to their taxonomic similarity. Similarity tree of floristic composition is constructed for the Arys River communities (Figures 7 \& 8) showing two divisional level clusters at similarity level $75 \%$, and three species diversity clusters at the similarity level $50 \%$. We implemented our spatial mapping approach $[10,25]$ for represent clusters on the basinal map of the Arys River. Cluster 2 (Figure 7) show similarity of divisional structure for upper and lower parts of the river basin whereas cluster 1 reflects difference in community structure of middle reaches. In the same time, species diversity similarity tree (Figure 8) is divided the river basin into three different parts in which are upper reaches (cluster 1), middle reaches of the Arys River and upper part of the Badam tributary (cluster 3), and lower reaches of the Arys and Badam (cluster 2). In the presented clustering maps is evident that algal communities diversity reflect the environmental differences between parts of basin that related with climatic trend correlated with the habitat altitude. Remarkable, that species diversity is more sensitive in the climate change.

The dendrite of taxonomic overlap (Figures $9 \& 10$ ) shows that the algal flora is divided into two clusters on the divisional level and four on the specie level similarity. Dendrite and map (Figure 9) demonstrate that division structure is similar in the upper tributaries parts and the middle reaches of the Arys River. However, species similarity dendrite show different picture (Figure 10) where basin of the river is divided into four parts closely related with the streams position: upper, left, right, and lower. It let us to assume that species diversity overlapping is correlated mostly with water variables than with climatic differences. In any case, the maps of clustering are very helpful for understanding of algal community distributions.

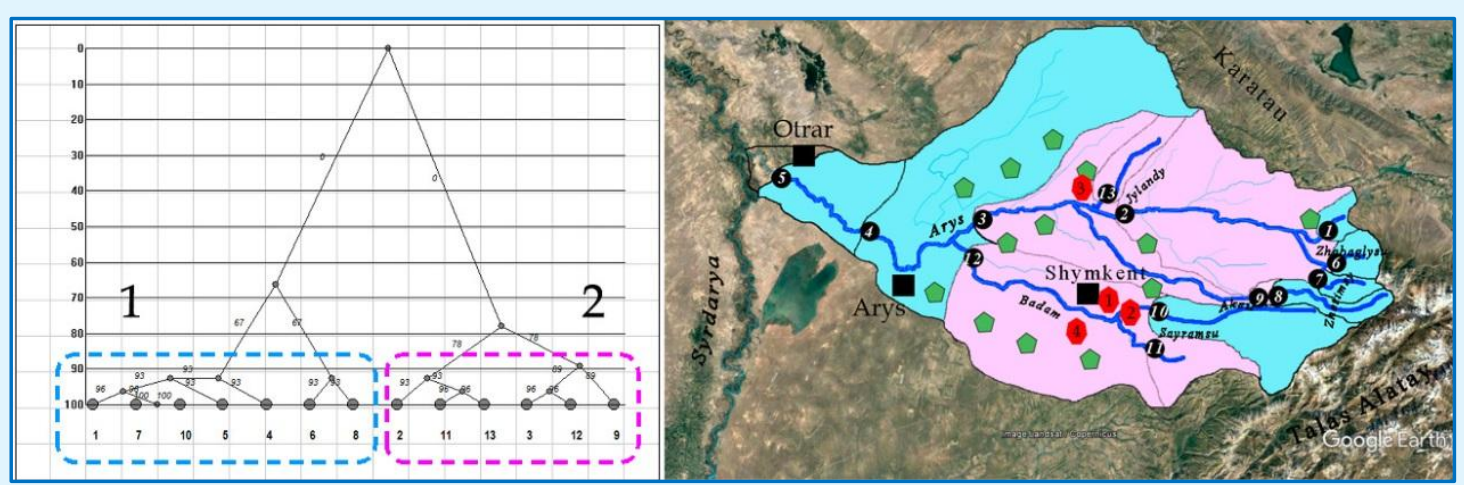

Figure 7: Dendrogram of divisional similarity of the Arys River communities and positions of clusters on the basinal map: blue - cluster 1, rose - cluster 2 .

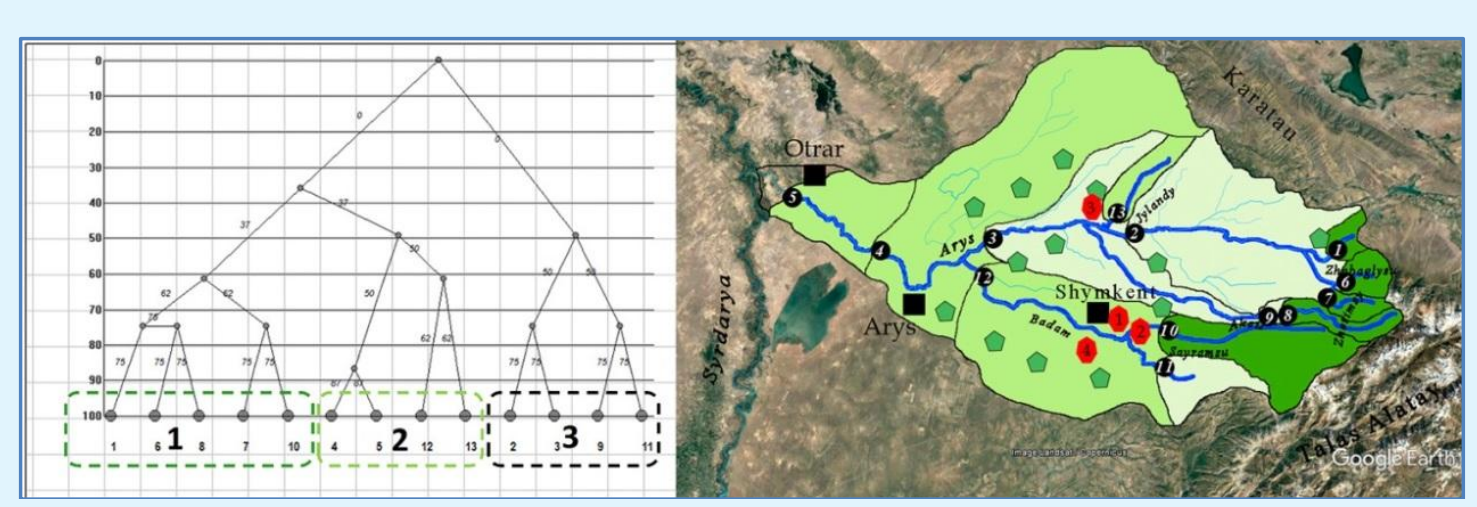

Figure 8: Dendrogram of species richness similarity of the Arys River communities and positions of clusters on the basinal map: dark green - cluster 1, light green - cluster 2 , white - cluster 3 . 


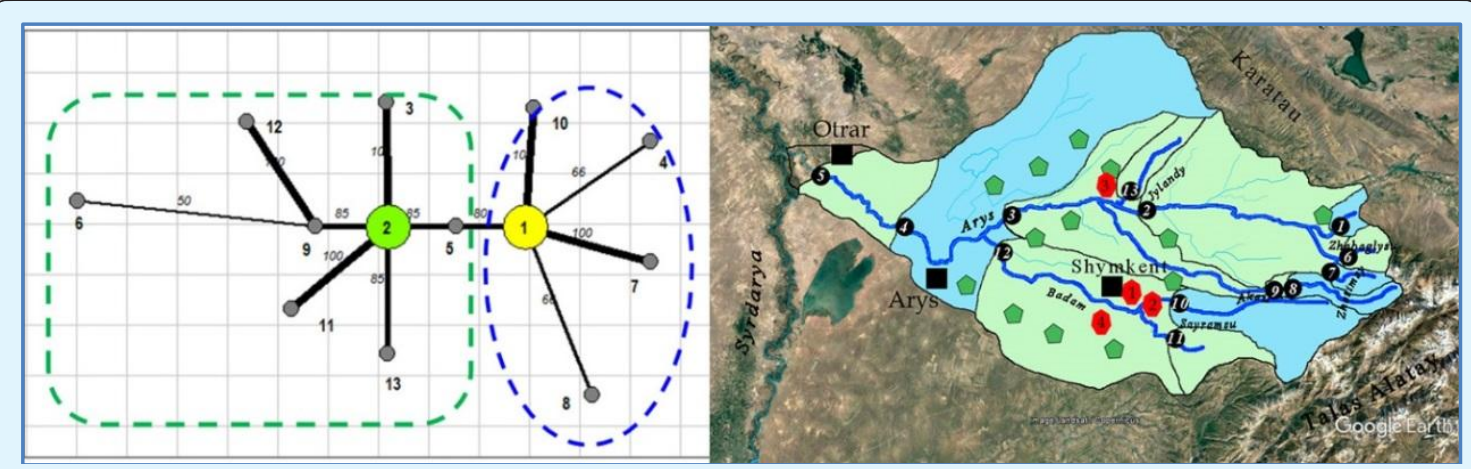

Figure 9: Dendrite of divisional overlapping of the Arys River communities and positions of clusters on the basinal map: blue - cluster 1, light green - cluster 2 .

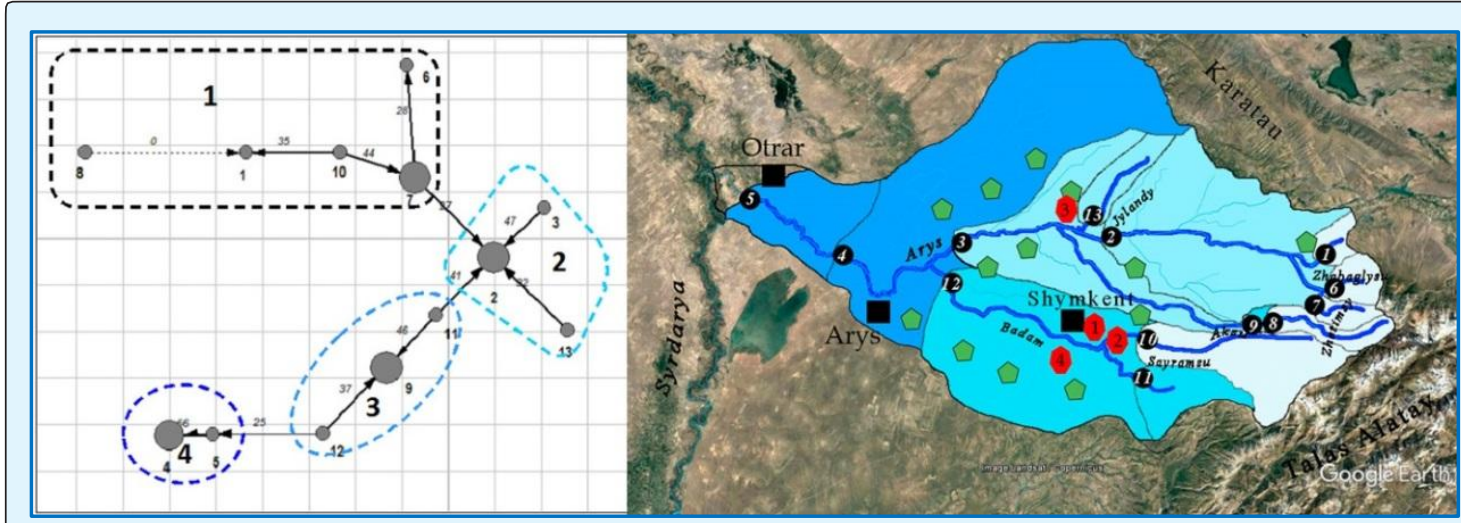

Figure 10: Dendrite of species richness overlapping of the Arys River communities and positions of clusters on the basinal map: white - cluster 1 , light blue - cluster 2 , blue - cluster 3 , dark blue cluster 4.

\section{Altitudinal Distribution of Algal and Cyanobacteria Diversity of the Arys River}

To infer the major factors of the alpha-diversity forming process we compared the taxonomic structure of algal floras and bioindication results from different parts of the river basin. As is evident from Table 1, altitude gradient of the different parts of the river is rather sharp. Whereas altitude of sampling points varied from $205 \mathrm{~m}$ to $1,513 \mathrm{~m}$ a.s.l, the altitude gradient is different for each tributary. The taxonomical diversity (Table 2) is varied between 13 species in lowland and 37 in mountain part of the basin. Figure 11 show species richness is varied significantly over the habitat altitude. Nevertheless, the trend line reflects the total species number is increased in the mountain. Divisional distribution over the habitat altitude (Figure 12) demonstrates that species richness is increased mostly with Bacillarioptyta species.

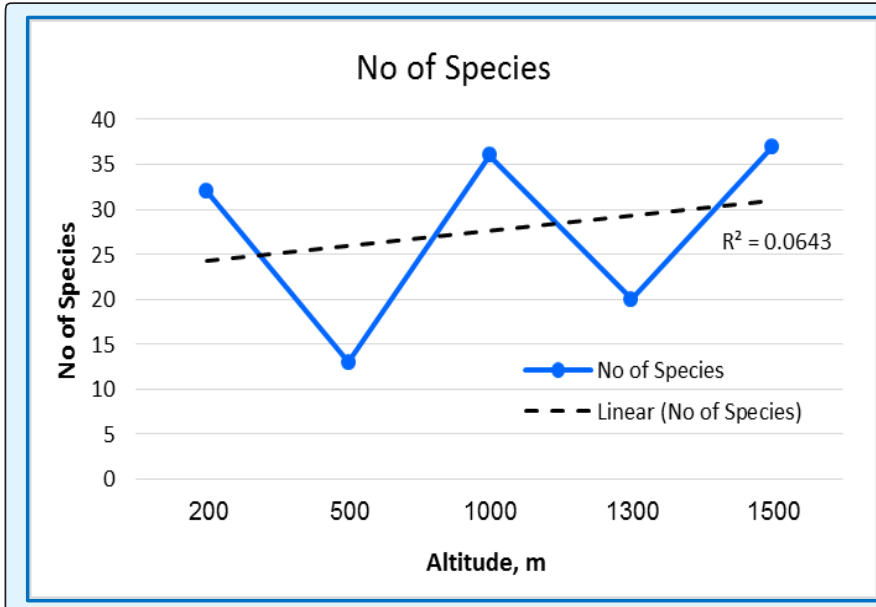

Figure 11: Distribution of species richness in the Arys River communities over altitude of habitats. 


\section{Journal of Ecology \& Natural Resources}

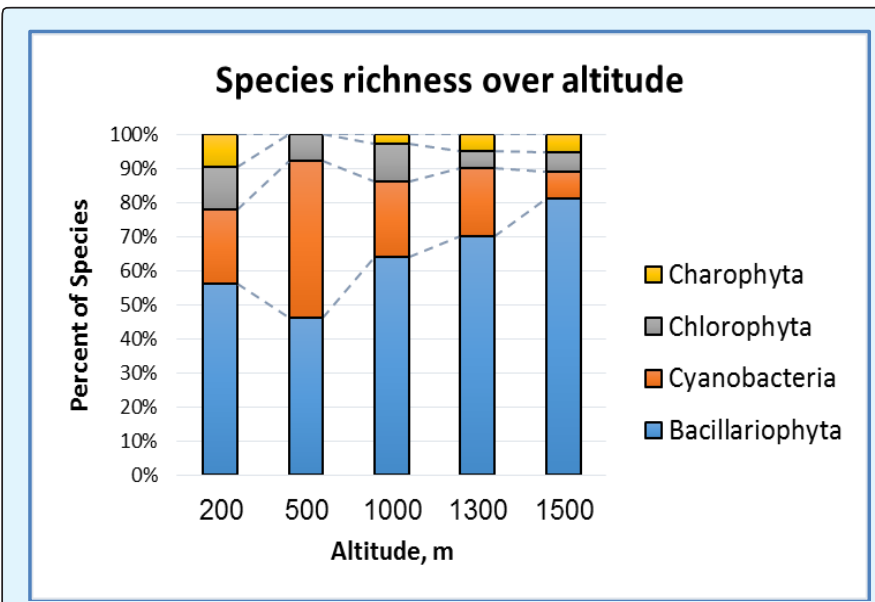

Figure 12: Distribution of species richness in taxonomic Divisions of the Arys River communities over altitude of habitats.
We analyzed the correlation of the algal species diversity in the Arys River basin with altitude of habitats with help of Statistica 12.0 Program. Figure 13 represents relationships of the species richness in taxonomic Divisions and altitude of the Arys River habitats. These plots show that species richness as a whole as well as Charophyta, Chlorophyta, and diatoms are decreased with altitude whereas Cyanobacteria diversity show opposite trend. This result is contrary in total species richness distribution (Figure 12) but similar of our calculation of algal diversity distribution in the Georgian Natural Reserves [7]. It can be related with climatic control of algal diversity in the territory of Southern Kazakhstan mountain part. The analysis, thus, reveals a strong altitude control over the major diversity estimates in the Arys River.

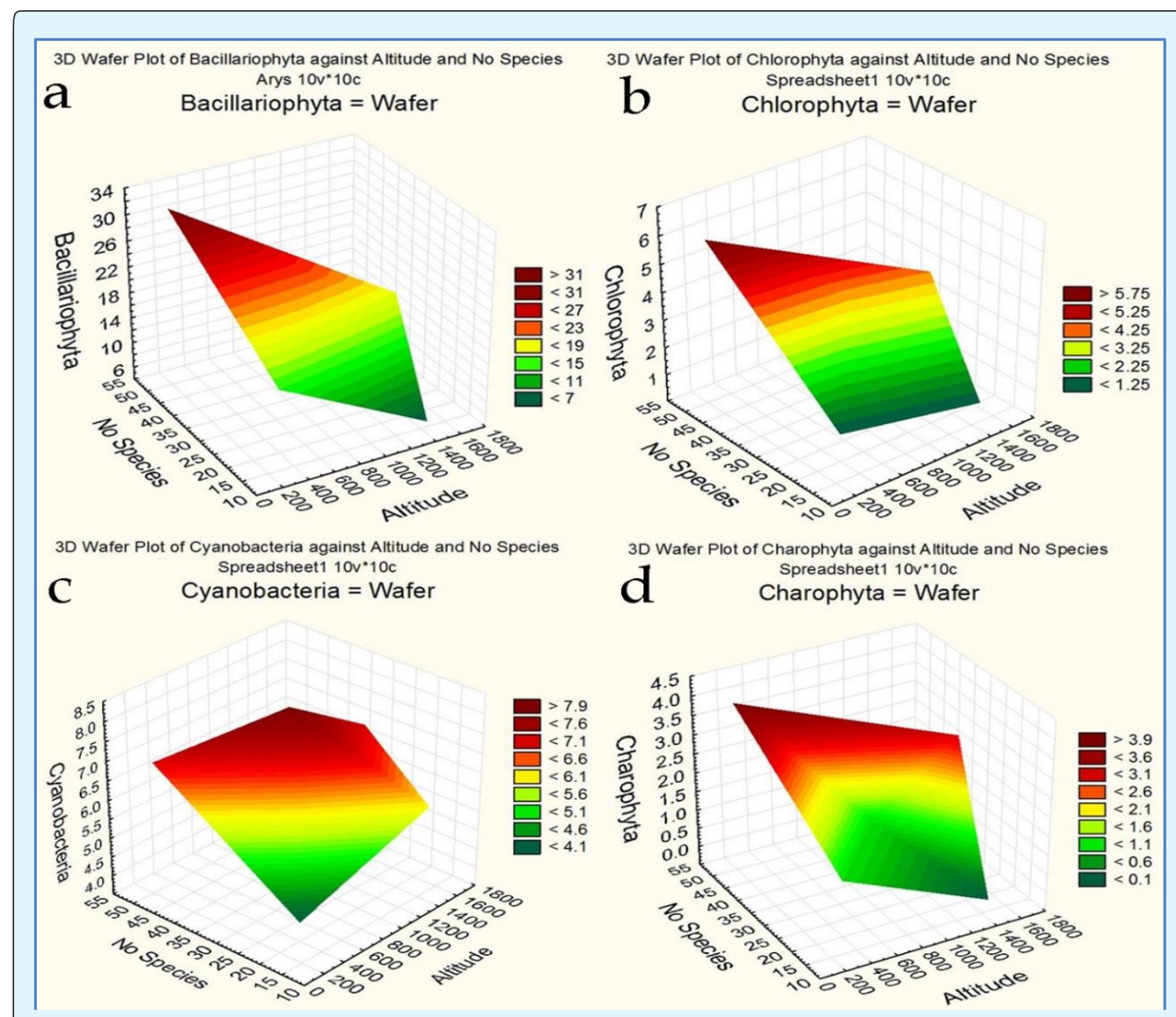

Figure 13: Surface plots of divisional distribution of the Arys River communities over altitude of habitats: a: Bacillariophyta; b: Chlorophyta; c: Cyanobacteria; d: Charophyta. 


\section{Journal of Ecology \& Natural Resources}

The algal floras are, as a whole, enriched by non-diatom algae and species richness increased with altitude in high mountain habitats of related boreal and arid regions such as Turkey [28,29] and Israel $[10,30]$. In contrast, our results show increasing in number of species but the number of diatom species with altitude increasing enriches communities. Our statistical calculation (Figure 13) demonstrates cryptic patterns in species diversity relation with altitude similar to mentioned floras. Therefore, we found that species diversity in the Arys River basin has similar distribution with the Swat River algal flora in Hindu Cush Mountains [11]. It allows us to assume that riverine algal communities have similar regulation of its diversity by high mountains climatic factors.

\section{Conclusion}

We represent first data about floristic diversity of algae and cyanobacteria in the Arys River basin and compared it to what is known about freshwater algae of the related mountain regions. Altogether 82 species are listed from 28 samples of phytoperiphyton on 13 sampling stations of the Arys River basin. Diatoms taxonomic division prevails in studied algal flora. Bioindication characterize the Arys River waters as temperate, moderately oxygenated, fresh, neutral water affected by a low to moderate level of organic pollution, Class II-III of water quality. The pattern of algal diversity distribution depends on altitude and local climatic conditions. Whereas Bacillariophyta was richest in high mountain habitats, green algae, cyanobacteria, and charophytes avoid high mountain habitats and have negative correlation with altitude. In the same time, cyanobacteria show very individual species richness although its total richness was not so large. These results can be used as indicator of environmental changes in the mountainous areas. Three floristic groups are recognized corresponding to the upper, middle and lower parts of the watershed. The general trend is an increase of species diversity from lowland areas to the high mountains.

As a conclusion, our analysis reveals the habitat altitude and related climatic factors control over the major algal diversity estimates in the Arys River basin habitats as the second largest river in Southern Kazakhstan.

\section{Acknowledgements}

This work was partly funded by the Israeli Ministry of Absorption. The work was carried out partly under the project № 1846/ГФ4 Г.2015-Г2017 for Committee of Science, Ministry of Education and Science, Republic of Kazakhstan "Development of the methods for controlling the ecological state of water bodies in Kazakhstan".

\section{References}

1. Barinova SS, Bragina TM, Nevo E (2009) Algal species diversity of arid region lakes in Kazakhstan and Israel. Community Ecology 10(1): 7-16.

2. Barinova S, Krupa E (2017) Bioindication of Ecological State and Water Quality by Phytoplankton in the Shardara Reservoir, Kazakhstan. Environment and Ecology Research 5(2): 73-92.

3. Krupa EG, Barinova SS, Romanova SM, Malybekov AB (2016) Hydrobiological assessment of the high mountain Kolsay lakes (Kungey Alatau, Southeastern Kazakhstan) ecosystems in climatic gradient. British Journal of Environment and Climate Change 6(4): 259-278.

4. Jaccard P (1912) The distribution of the flora in the alpine zone. The New Phytologist 11(2): 37-50.

5. Qian H, White PS, Song JS (2007) Effects of regional vs. ecological factors on plant species richness: an intercontinental analysis. Ecology 88(6): 1440-1453.

6. Qian H, White PS, Klinka K, Chourmouzis C (1999) Phytogeographical and community similarities of alpine tundras of Changbaishan Summit, China, and Indian Peaks, USA. J Vegetation Sci 10(6): 869-882.

7. Barinova SS, Kukhaleishvili L, Nevo E, Janelidze Z (2011) Diversity and ecology of algae in the Algeti National Park as a part of the Georgian system of protected areas. Turk J Bot 35: 729-774.

8. Barinova S, Kukhaleishvili L (2014) Diversity and ecology of algae and cyanobacteria in the Aragvi River, Georgia. The Journal of Biodiversity. Photon 113: 305-338.

9. Barinova S, Kukhaleishvili L (2017) Diversity and ecology of algae and cyanobacteria in the Enguri River, Georgia. Elixir Bio Sci 104: 45934-45947.

10. Barinova S (2011) The effect of altitude on distribution of freshwater algae in continental Israel. Current Topics of Plant Biology 12: 89-95. 


\section{Journal of Ecology \& Natural Resources}

11. Barinova S, Naiz Ali, Barkatullah, Sarim FM (2013) Ecological adaptation to altitude of algal communities in the Swat Valley (Hindu Cush Mountains, Pakistan). Expert Opin Environ Biol 2(2): 1-15.

12. Heywood V (2004) Modern approaches to floristics and their impact on the region of SW Asia. Turk J Bot 28: 7-16.

13. Zinzani A (2015) Irrigation Management Transfer and WUAs' dynamics: evidence from the SouthKazakhstan Province. Environ Earth Sci 73(2): 765777.

14. Solodukhin VP, Poznyak VL, Kazachevskiy IV, Knyazev BB, Lukashenko S, et al. (2004) Some peculiarities of the contamination with radionuclides and toxic elements of the Syrdarya river basin, Kazakhstan Journal of Radioanalytical and Nuclear Chemistry 259(2): 245-250.

15. Whitton BA, Rott E, Friedrich G (1991) Use of algae for monitoring rivers. Innsbruck: Institut für Botanik University Press.

16. Semenova AD (1977) Guideline for chemical analysis of surface water, Leningrad, Russia: Gidrometeoizdat (In Russian).

17. Fomin GS (1995) Water Control of chemical, bacterial and radiation safety according to international standards, Moscow, Russia: NGO "Alternative" (In Russian).

18. Kiselev IA (1956) Methods of study of plankton. Life of freshwaters of the USSR. [Metody issledovaniya planktona. Jizn presnyh vod SSSR]. 4th (Vol.), Moscow, Leningrad: USSR Academy of Sciences (In Russian).

19. Zabelina MM, Kiselev IA, Proshkina-Lavrenko AI, Sheshukova VS (1951) Key to freshwater algae USSR. 4(Vol.), Diatoms. [Opredelitel presnovodnyh vodoroslei SSSR. Diatomovye vodorosli]. Moscow: Soviet Science (In Russian).

20. Gollerbach MM, Kossinskaya EK, Polyansky VI (1953) Key to freshwater algae of USSR. 2(Vol.), Blue-green algae. [Opredelitel presnovodnyh vodoroslei SSSR. Sine-zelenye vodorosli]. Moscow: Soviet Science (In Russian).
21. Popova TG (1955) Key to freshwater algae USSR. 7(Vol.), Euglenophyta. [Opredelitel presnovodnyh vodoroslei SSSR. Evglenovye vodorosli]. Moscow: Soviet Science (In Russian).

22. Palamar-Mordvintseva GM (1982) Key to freshwater algae USSR. 11(2) (Vol.), Green algae. Class Conjugatophyceae. Desmidiaceae (2). [Opredelitel presnovodnih vodoroslei SSSR. Zelenye vodorosli. Klass Konugaty. Poryadok Desmidievie]. Moscow: Soviet Science (In Russian).

23. Moshkova NA, Gollerbach MM (1986) Key to freshwater algae USSR. 10(1) (Vol.), Green algae. Class Ulothrichophyceae. [Opredelitel presnovodnih vodoroslei SSSR. Zelenie vodorosli. Class Ulotriksovye.]. Moscow: Soviet Science (In Russian).

24. Novakovsky AB (2004) Abilities and base principles of program module "GRAPHS". Syktyvkar, Komi Scientific Center, Ural Branch of Russian Academy of Science 27: 1-28.

25. Barinova S (2017) Ecological mapping in application to aquatic ecosystems bioindication: problems and methods. International Journal of Environmental Sciences \& Natural Resources, in Press.

26. Barinova SS, Medvedeva LA, Anissimova OV (2006) Diversity of algal indicators in environmental assessment. Tel Aviv: Pilies Studio.

27. Van Dam H, Mertens A, Sinkeldam J (1994) A coded checklist and ecological indicator values of freshwater diatoms from The Netherlands. Netherlands Journal of Aquatic Ecology 28(1): 117133.

28. Kara H, Şahin B (2001) Epipelic and epilithic algae of Degirmendere River (Trabzon-Turkey). Turk J Bot 25: 177-186.

29. Sahin B (2003) Epipelic and epilithic algae of lower parts of Yanbolu River (Trabzon, Turkey). Turk J Biol 27: 107-115.

30. Barinova S (2011) Algal diversity dynamics, ecological assessment, and monitoring in the river ecosystems of the eastern Mediterranean. Nova Science Publishers, USA. 